\title{
Classification of phytoplasma strains in the elm yellows group (16SrV) and proposal of 'Candidatus Phytoplasma ulmi' for the phytoplasma associated with elm yellows
}

\author{
Ing-Ming Lee, ${ }^{1}$ Marta Martini, ${ }^{1,2}$ Carmine Marcone ${ }^{3}$ and Shifang F. Zhu ${ }^{1,4}$ \\ ${ }^{1}$ USDA-ARS Molecular Plant Pathology Laboratory, Beltsville, MD 20705, USA \\ ${ }^{2}$ Dipartimento di Biologia Applicata alla Difesa delle Piante, University of Udine, 33100 Udine, \\ Italy \\ ${ }^{3}$ Dipartimento di Biologia, Difesa e Biotecnologie Agro-Forestali, University of Basilicata, \\ 85100 Potenza, Italy \\ ${ }^{4}$ Institute of Animal and Plant Quarantine, Beijing 10029, PR China
}

\begin{abstract}
Elm yellows group (16SrV) phytoplasmas, which are associated with devastating diseases in elm, grapevine, blackberry, cherry, peach and several other plant species in America, Europe and Asia, represent one of the most diverse phytoplasma clusters. On the basis of phylogenetic analysis of $16 \mathrm{~S}$ rDNA sequences, elm yellows group phytoplasmas form a discrete subclade within the phytoplasma clade. Three phylogenetic parameters, namely $16 S$ rRNA, ribosomal protein and $\sec Y$ genes, have been evaluated for their usefulness in differentiating elm yellows group phytoplasmas. RFLP analysis of $16 \mathrm{~S}$ rRNA sequences differentiated the elm yellows group phytoplasmas into five subgroups. Twelve RFLP subgroups were differentiated on the basis of ribosomal protein and 13 were differentiated using $\sec Y$ gene sequences. Phylogenetic analysis of the ribosomal protein genes and $\sec Y$ gene alone or in combination indicated that the subgroups constitute 12 genetically distinct lineages, each of which appears to have evolved under different ecological constraints such as specific vector or plant hosts. On the basis of unique DNA and biological properties, it is proposed that the elm yellows phytoplasma EY $1^{\top}$ represents a novel taxon, 'Candidatus Phytoplasma ulmi'.
\end{abstract}

\section{INTRODUCTION}

The highly conserved 16S rRNA gene sequence has been used as the primary phylogenetic parameter for classification of phytoplasmas in the emerging phytoplasma taxonomy (Lee et al., 1993b, 1998a; Schneider et al., 1995; Seemüller et al., 1994, 1998). On the basis of extensive RFLP or phylogenetic analyses of $16 \mathrm{~S}$ rDNA sequences from a wide array of phytoplasma strains, more than 20 distinct phytoplasma groups have been identified (Lee

\footnotetext{
Abbreviations: ALY, alder yellows; CLY, cherry lethal yellows; EY, elm yellows; FD, flavescence dorée; HD, hemp dogbane; JWB, jujube witches'-broom; PY-In, peach yellows; RuS, rubus stunt; SpaWB, spartium witches'-broom.

The GenBank accession numbers for the sequences of elm yellows phytoplasma strain $E Y 1^{\top}$ are AY197655 (16S rDNA), AY197675 (rp/22-rps3) and AY197690 (secY).

Details of RFLP pattern groups for $16 \mathrm{~S}$ rDNA and ribosomal protein operons and putative restriction maps from ribosomal protein and sec $Y$ gene sequences of representative EY phytoplasmas are available as supplementary material in IJSEM Online.
}

et al., 2000; Seemüller et al., 1998). Each group was proposed to represent at least one species (Gundersen et al., 1994; Seemüller et al., 1998). Because it continues to be impossible to obtain a pure culture of any phytoplasma, a provisional taxonomic system for uncultured bacteria proposed by Murray \& Schleifer (1994) was adopted, with some modifications, for the naming of phytoplasma species candidates. So far, nine 'Candidatus Phytoplasma' species have been proposed (Lee et al., 2000; Jung et al., 2002; Verdin et al., 2003). The elm yellows (EY) group ( $=16 \mathrm{SrV}$ group, delineated using RFLP analysis) represents one of the major phytoplasma groups identified.

The EY phytoplasma (16SrV) group consists of diverse phytoplasma strains, representing the third largest phytoplasma cluster after the aster yellows and X-disease phytoplasma groups (Gundersen et al., 1996; Lee et al., 2000). EY phytoplasma strains $\left(\mathrm{EY} 1^{\mathrm{T}}, \mathrm{EY} 125, \mathrm{EY} 626\right.$ and others) have caused a decline in American elms in North America and Eurasian elm species and hybrids in several European countries (Griffiths et al., 1999a; Lee et al., 1993a, 1995; Marcone et al., 1997; Mäurer et al., 1993; Sinclair 
et al., 1976). Strain $\mathrm{EY}^{\mathrm{T}}$ is the reference phytoplasma strain for the EY phytoplasma group (Lee et al., 1993b). Other EY group phytoplasmas associated with diseases in diverse plant genera in various geographical regions are as follows: flavescence dorée (FD) and grapevine yellows phytoplasmas in the European grapevine (Bertaccini et al., 1997; Daire et al., 1997; Martini et al., 2002; Seemüller et al., 1994); rubus stunt (RuS) phytoplasmas in wild and cultivated blackberries (Rubus spp.) in Europe (Lee et al., 1995; Mäurer \& Seemüller, 1994; Marcone et al., 1997); a strain of the cherry lethal yellows (CLY) phytoplasma (CLY5) in the cherry in China (Zhu et al., 1997); peach yellows (PY-In) phytoplasma in peach in India; jujube witches'broom (JWB) phytoplasma in Ziziphus spp. in China and India (Tian et al., 2000; Zhu et al., 1997); alder yellows (ALY) phytoplasmas in alder in several European countries (Marcone et al., 1997; Mäurer et al., 1993); spartium witches'-broom (SpaWB)-EY phytoplasma in Spartium sp. in Italy (Marcone et al., 1996a); eucalyptus little leaf phytoplasma in Eucalyptus sp. in Italy (Marcone et al., 1996b); and hemp dogbane (HD)-associated phytoplasma (HD1) in Apocynum cannabinum in New York state (Griffiths et al., 1999a). Recently, a novel EY group phytoplasma, Virginia creeper phytoplasma, was reported to infect Virginia creeper (Parthenocissus quinquefolia) plants in southern Florida (Harrison et al., 2001) and an EY-related phytoplasma was reported to infect tomato plants in Italy (Del Serrone et al., 2001). Many diseases inflicted by EY group phytoplasmas are economically important and are subject to quarantine internationally.

Members of the EY phytoplasma group appear to be homogeneous on the basis of 16S rRNA gene sequences: they share 98.6-99.9\% similarity (Lee et al., 1998a). However, despite their close relatedness (on the basis of $16 S$ rRNA sequences), EY group phytoplasmas apparently constitute several strain clusters that share no common ecological niches (Lee et al., 1998b). In nature, they are transmitted by different insect vectors and are associated with different plant hosts in various geographical regions. For epidemiological studies and for quarantine purposes, it is necessary to have a classification system that allows the differentiation of these ecologically distinct strains in the EY group. EY group phytoplasmas have been classified into five subgroups based on $16 \mathrm{~S}$ rDNA sequences (Davis \& Dally, 2001; Lee et al., 1998a; Martini et al., 1999). This approach was found to be insufficient for differentiating many members of this group, of which several strains (or strain clusters) have been shown to be distinct according to biological or pathological properties. Many studies have focused on finer differentiation of phytoplasma strains associated with FD and grapevine yellows phytoplasma diseases in grapevine (Angelini et al., 2001; Daire et al., 1997; Davis et al., 1997; Martini et al., 1999, 2002). On the basis of analysis of a non-rDNA fragment, FD9, encoding a translocase protein (secY) and a partial ribosomal protein (rpl15) (Reinert, 1999), several distinct subgroups were identified. However, there is no comprehensive classification scheme for differentiation and identification of all members of the expanded EY phytoplasma group.

The objectives of the present study were to investigate phylogenetic relationships among members of the expanded EY phytoplasma group, using combined analyses of the $16 \mathrm{~S}$ rRNA, ribosomal protein and $\sec Y$ gene sequences, and to evaluate new phylogenetic parameters for finer strain differentiation. In this study, we report RFLP subgroups identified on the basis of these gene sequences. Phylogenies based on these three genes have strengthened the notion that the EY phytoplasma group consists of heterogeneous phytoplasma strains that represent several distinct phylogenetic clusters. The phylogenetic and biological criteria are consistent with the concept that the EY phytoplasma group comprises more than one species. In this paper, we propose that the EY phytoplasma strain $\mathrm{EY}^{\mathrm{T}}$ (a member of subgroup 16SrV-A) associated with EY in the American elm represents a novel 'Candidatus' phytoplasma species, 'Candidatus Phytoplasma ulmi'.

\section{METHODS}

Phytoplasma strains and nucleic acid preparation. All representative EY phytoplasma strains listed in Table 1, except strains FD (Lom/Piem) and Virginia creeper phytoplasma, were used in the present study. Total nucleic acid or DNA was extracted using leaf midribs or other tissues from periwinkle or the original hosts that were infected by representative phytoplasma strains according to the method described by Ahrens \& Seemüller (1992) or Lee et al. (1993a). These representative phytoplasma strains were previously characterized and identified by RFLP or sequence analysis of $16 \mathrm{~S}$ rDNA (Lee et al., 1993b, 1998a; Davis \& Dally, 2001; Martini et al., 1999; Marcone et al., 1997).

RFLP and putative restriction map analyses. RFLP analyses of three conserved genes, $16 \mathrm{~S}$ rRNA, ribosomal protein and $\sec Y$ (a translocase gene), were evaluated for their usefulness in differentiating EY group phytoplasmas. Partial $16 \mathrm{~S}$ rDNA sequences were prepared by using a nested PCR with universal primer pair P1/P7 (Schneider et al., 1995) followed by universal primer pair R16F2n/ R16R2 (Gundersen \& Lee, 1996). R16F2n/R16R2 PCR products $(1 \cdot 2 \mathrm{~kb})$ were digested with restriction enzymes MseI, AluI, Sau3AI, ThaI, HaeIII, BfaI, RsaI, HpaII and Tsp509I. To differentiate FD-D from other members of the EY group, nearly full-length $16 \mathrm{~S}$ rDNA (about $1.5 \mathrm{~kb}$ ) was amplified by using a nested PCR with primer pair P1/P7 followed by P1A (5'-AACGCTGGCGGCGCGCCTAATAC$3^{\prime}$ ) and 16S-SR (5'-GGTCTGTCAAAACTGAAGATG-3') (designed in this study). The P1A/16S-SR PCR products were digested with TaqI. To prepare the ribosomal protein gene operon, a nested PCR was performed using the ribosomal protein primer pair $\mathrm{rp}(\mathrm{V}) \mathrm{F} 1 /$ rpR1 specific to the EY phytoplasma group (Lee et al., 1998a; Lim \& Sears, 1992) followed by another EY group-specific primer pair, rp(V)F1A (5'-AGGCGATAAAAAAGTTTCAAAA-3') and rp(V)R1A (5'-GGCATTAACATAATATATTATG-3') (designed in this study). The nested PCR with primer pair $\operatorname{rp}(\mathrm{V}) \mathrm{F} 1 \mathrm{~A} / \mathrm{rp}(\mathrm{V}) \mathrm{R} 1 \mathrm{~A}$ yielded a DNA fragment (about $1.2 \mathrm{~kb}$ ) that covered the region with ribosomal protein genes $s 3$ and 122 . Nested PCR products were digested with restriction enzymes HpaII, HaeIII, HhaI, DraI, SspI, TaqI, AluI, Tsp509I and MseI. Restriction fragments were visualized according to the procedures described previously (Lee et al., 1993b, 1998a). To prepare secY gene sequences, an FD9 DNA fragment $(1.4 \mathrm{~kb})$ encoding the $3^{\prime}$-end of rpll5 and the $\sec Y$ gene was amplified using the primer pair FD9f/r reported previously by Daire et al. (1997). 
Table 1. Designations, associated diseases and origins of representative phytoplasma strains in the EY phytoplasma group (16SrV)

\begin{tabular}{|c|c|c|c|c|c|c|}
\hline Strain & Disease/host & Insect vector & Origin & \multicolumn{3}{|c|}{ RFLP classification subgroup } \\
\hline RuS400 & Rubus stunt, Rubus fruticosus & Unknown & Italy & $\mathrm{E}$ & I & \\
\hline RuS971 & Rubus stunt, Rubus idaeus & Unknown & Switzerland & $\mathrm{E}$ & I & \\
\hline RUS & Rubus stunt, periwinkle & Unknown & Italy & $\mathrm{E}$ & I & I \\
\hline ALY1068 & Alder yellows, Alnus glutinosa & Unknown & Italy & $\mathrm{C}$ & $\mathrm{H}$ & \\
\hline HD1 & Hemp dogbane, Apocynum cannabinum & Unknown & NY, USA & $\mathrm{C}$ & $\mathrm{J}$ & $\mathrm{J}$ \\
\hline FD70 & Flavescence dorée, Vitis vinifera & Scaphoideus titanus & France & $\mathrm{C}$ & $\mathrm{F}$ & $\mathrm{F}$ \\
\hline FD-D & Flavescence dorée, Vitis vinifera & Scaphoideus titanus & Italy & $\mathrm{D}$ & $\mathrm{E}$ & $\mathrm{E}$ \\
\hline FD-C & Flavescence dorée, Vitis vinifera & Scaphoideus titanus & Italy & $\mathrm{C}$ & $\mathrm{D}$ & $\mathrm{D}$ \\
\hline $\mathrm{EY} 1^{\mathrm{T}}$ & Elm yellows, Ulmus americana & Scaphoideus luteolus & NY, USA & A & A & A \\
\hline EY125 & Elm yellows, Ulmus minor & Unknown & Italy & A & A & \\
\hline EY626 & Elm yellows, Ulmus minor & Unknown & Italy & A & A & M \\
\hline EY627 & Elm yellows, Ulmus minor & Unknown & Italy & A & A & \\
\hline JWB & Jujube witches'-broom, Ziziphus jujuba & Hishimonoides chinesis & China & $\mathrm{B}$ & $\mathrm{C}$ & $\mathrm{C}$ \\
\hline PY-In & Peach yellows, Prunus persica & Unknown & India & B & $\mathrm{M}$ & $\mathrm{N}$ \\
\hline CLY5 & Cherry lethal yellows, Prunus avium & Unknown & China & $\mathrm{B}$ & $\mathrm{B}$ & B \\
\hline
\end{tabular}

Putative restriction maps of the $\sec Y$ DNA fragment $(1 \cdot 2 \mathrm{~kb})$ and the $1.2 \mathrm{~kb}$ rp DNA fragment from representative phytoplasma strains were generated by using the DNASTAR program MapDraw option.

Cloning of PCR products and sequencing of DNA. PCRamplified products of $16 \mathrm{~S}$ rRNA, ribosomal protein and $\sec Y$ genes were cloned and sequenced. To obtain nearly full-length $16 \mathrm{~S}$ rDNA, P1A/P7A PCR products (about $1.8 \mathrm{~kb}$ long and extending from the $5^{\prime}$-end of $16 \mathrm{~S}$ rRNA, through the intergenic spacer region, to the 3 '-end of the 23S rRNA) were cloned. P1A/P7A DNA fragments were amplified using diluted P1/P7 PCR products as templates in a PCR using the universal primer pair P1A/P7A (5'-ACGCTGGCGGCGCGCCTAATAC-3' $/ 5^{\prime}$-CCTTCATCGGCTCTTAGTGC- ${ }^{\prime}$ ). The P1A/P7A PCR products, $r p(\mathrm{~V}) \mathrm{F} 1 \mathrm{~A} / \mathrm{rp}(\mathrm{V}) \mathrm{R} 1 \mathrm{~A}$ PCR products (about $1.2 \mathrm{~kb}$ long, containing the rpl22-rps3 gene sequence) and FD9f/r PCR products (about $1.4 \mathrm{~kb}$ long, containing the $\sec Y$ gene sequence) were purified using the Qiaquick PCR purification kit (Qiagen) and cloned into Escherichia coli by using the TOPO TA cloning kit (Invitrogen) according to the manufacturers' instructions. Sequencing was performed with an automated DNA sequencer (model 377; ABI Prism) at the Center for Agricultural Biotechnology (University of Maryland, College Park, MD, USA). Cloned nucleotide sequences were deposited in GenBank (see Figs 3 and 4 for accession numbers).

Phylogenetic analysis. Phylogenetic interrelationships among strains of the EY group and other phytoplasma groups were assessed on the basis of $16 \mathrm{~S}$ rRNA gene sequences. Partial sequences of $16 \mathrm{~S}$ rDNA $(1.5 \mathrm{~kb})$ from members of the EY phytoplasma group and representative phytoplasma strains available in GenBank were aligned by using CLUSTAL V (Higgins \& Sharp, 1989) and LASERGENE software (DNAStar). Cladistic analyses were performed with PAUP, version 4.0 (Swofford, 1998), on a Power Mac G4. Uninformative characters were excluded from analyses. A phylogenetic tree was constructed by using a heuristic search via random stepwise addition, implementing the tree bisection and reconnection branchswapping algorithm to find the optimal tree(s) (Gundersen et al., 1994). Acholeplasma laidlawii JA1 was selected as the outgroup to root the tree. The analysis was replicated 1000 times. Bootstrapping was performed to estimate the stability and support for the inferred clades. Finer phylogenetic relationships among representative members of the EY phytoplasma group were determined on the basis of sequences of a partial ribosomal protein gene operon $(1.2 \mathrm{~kb}$, covering the rpl22 and rps3 genes) and a translocase protein gene, secY $(1 \cdot 2 \mathrm{~kb})$. Deduced amino acid sequences of ribosomal protein $(r p l 22$ and $r p s 3)$ and $\sec Y$ genes from representative subgroups were also compared. Potato witches'-broom phytoplasma (GenBank accession no. AY197683), a member of subgroup 16SrVI-A, was selected as the outgroup for ribosomal protein gene analysis and Bacillus subtilis 168 (AL009126) was selected as the outgroup for $\sec Y$ gene and ribosomal protein/sec $Y$ genes combined.

\section{RESULTS AND DISCUSSION}

\section{Strain differentiation by RFLP analysis}

Gene sequences of $16 \mathrm{~S}$ rRNA and ribosomal protein were compared for efficacy for finer strain differentiation among members of the EY phytoplasma group. Collective profiles obtained from digests of partial 16S rDNA $(1 \cdot 2 \mathrm{~kb}$; a nested PCR product with primer pair R16F2n/R16R2) sequences from all 20 representative members of the EY 
phytoplasma group with RsaI, HpaII, Tsp509I and BfaI differentiated four distinct subgroups (16SrV-A, 16SrV-B, $16 \mathrm{SrV}-\mathrm{C}$ and $16 \mathrm{SrV}-\mathrm{E}$ ) of the EY group (Fig. 1, Table 1) (see also Supplementary Table A in IJSEM Online). Sequence alignment of the $1.8 \mathrm{~kb}$ P1/P7 DNA fragment, which contains nearly the entire 16S rRNA gene and 16S-23S spacer region, of all $20 \mathrm{EY}$ group phytoplasma strains revealed that additional sequence variations were present in the regions of $16 \mathrm{~S}$ rRNA outside the portion covered by primers R16F2n/ R16R2. One additional $16 \mathrm{SrV}$ subgroup (16SrV-D) was recognized on the basis of a unique TaqI restriction site present in these regions in strain FD-D (Fig. 1e). Variations were also found in the spacer regions, but these were not used for $16 \mathrm{SrV}$ subgroup differentiation since $16 \mathrm{Sr}$ groups or subgroups were defined on the basis of 16S rRNA gene sequences. New members of each subgroup were designated on the basis of collective RFLP profiles (Table 1). Strains EY1 ${ }^{\mathrm{T}}$, EY125, EY626 and EY627 belonged to subgroup 16SrV-A with profile type A; strains CLY5, JWB and PY-In belonged to subgroup $16 \mathrm{SrV}$-B with profile type B; strains ALY, ALY882, ALY1068, HD1, FD 70, FD-C, SpaWB229 and SpaWB251 belonged to subgroup 16SrV-C with profile type C; strain FD-D belonged to subgroup 16SrV-D with profile type D; and strains RuSR19, RuS400, RuS971 and RUS belonged to subgroup 16SrV-E with profile type E. RFLP patterns of MseI and AluI digests of $16 \mathrm{~S}$ rDNA were identical among all strains analysed, and the patterns were unique to this group (Lee et al., 1998a) (Fig. 1, Table 1). Patterns of ThaI, Sau3AI and HaeIII digests were also identical (data not shown).

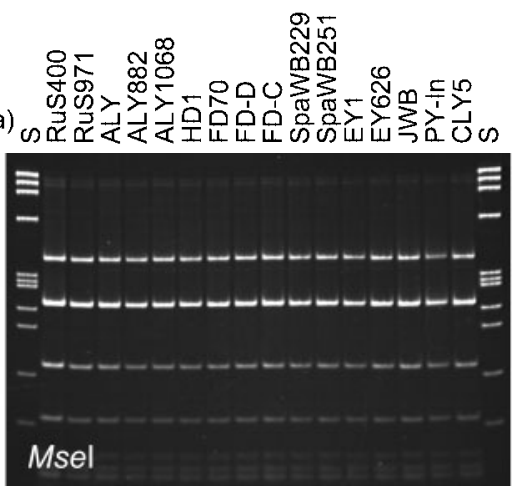

(d)

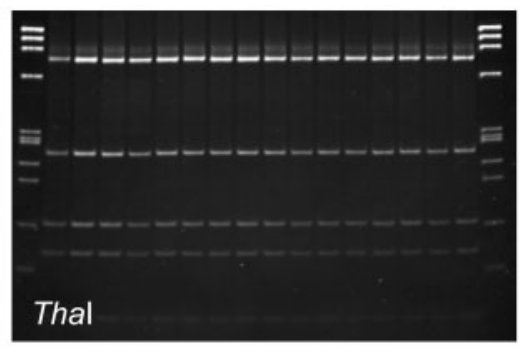

(g)

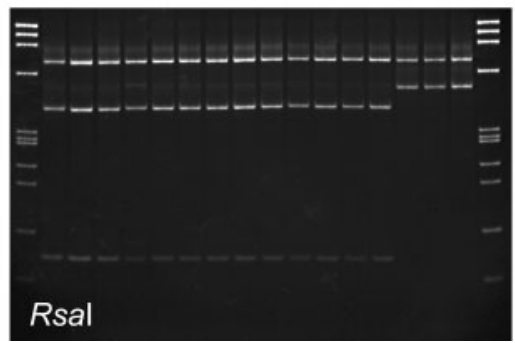

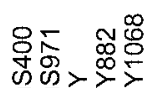

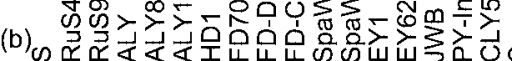

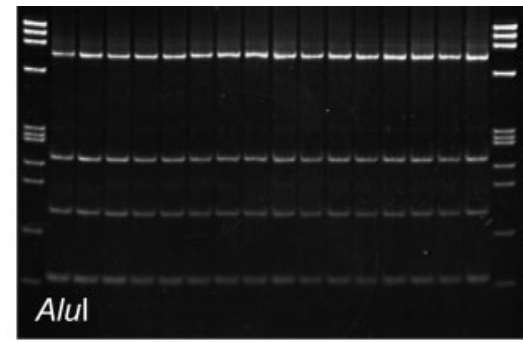

(e)

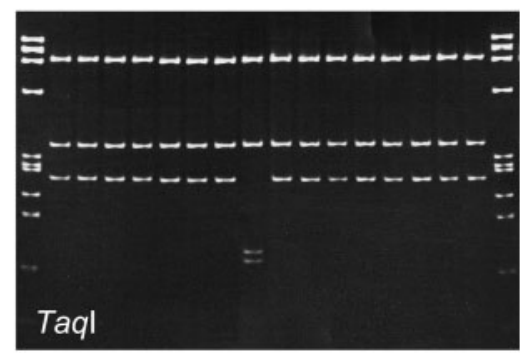

(h)

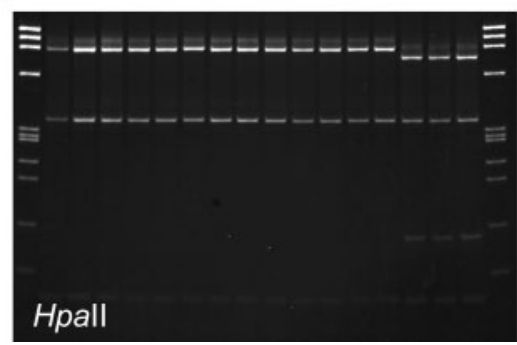

(c) फㅇำ

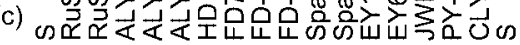

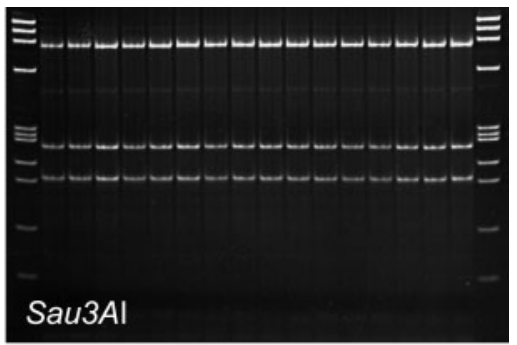

(f)

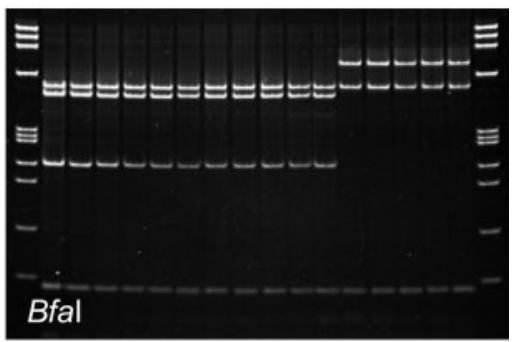

(i)

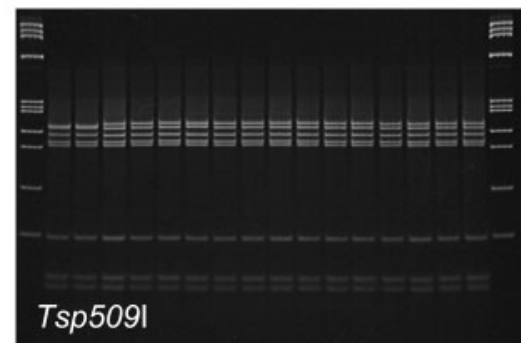

Fig. 1. RFLP profiles of $1 \cdot 2 \mathrm{~kb} 16 \mathrm{~S}$ rDNA $(\mathrm{a}-\mathrm{d}, \mathrm{f}-\mathrm{i})$ amplified by nested $P C R$ with primer pair $P 1 / \mathrm{P} 7$ followed by primer pair R16F2n/R16R2 and 1.5 kb 16S rDNA (e) amplified by nested PCR with primer pair P1/P7 followed by primer pair P1A/16S$\mathrm{SR}$, from representative phytoplasma strains in the EY phytoplasma group (16SrV). PCR products were digested with Msel (a), Alul (b), Sau3Al (c), Thal (d), Taql (e), Bfal (f), Rsal (g), Hpall (h) or Tsp509l (i) and separated by electrophoresis through $5 \%$ (12\% for Tsp509I digests) polyacrylamide gels. Lanes S, $\phi$ X174 replicating form I DNA Haell digest; fragment sizes (bp) from top to bottom: $1353,1078,872,603,310,281,271,234,194,118,72$. Other abbreviations are defined in Table 1. 
RFLP analyses of ribosomal protein gene sequences resulted in finer differentiation among the $20 \mathrm{EY}$ phytoplasma strains. Collective profiles obtained from digests with restriction enzymes MseI, Tsp509I, AluI, TaqI, HaeIII, HpaII, HhaI, DraI and SspI differentiated 12 distinct ribosomal protein subgroups within the EY group (Fig. 2, Table 1). The RFLP pattern types with individual enzymes and ribosomal protein subgroup designations are summarized in Table 1. Seven distinct ribosomal protein RFLP pattern types (subgroups) were differentiated among members of $16 \mathrm{SrV}-\mathrm{C}$ included in the present study, and three ribosomal protein RFLP pattern types (subgroups) were differentiated among members of $16 \mathrm{SrV}-\mathrm{B}$ (Supplementary Table B). Eight ribosomal protein subgroups identified in the present study were consistent with those identified by Martini et al. (2002).

Subgroups delineated on the basis of putative restriction maps were generally consistent with those based on RFLP analyses (Supplementary Fig. A). Twelve rpV subgroups were differentiated on the basis of putative restriction sites; these subgroups are consistent with subgroups identified on the basis of actual RFLP analysis of the $1 \cdot 2 \mathrm{~kb}$ ribosomal protein operon sequences.

Restriction map analysis of $\sec Y$ sequences delineated 13 subgroups, 12 of which coincided with their corresponding ribosomal protein subgroups (Table 1; see also Supplementary

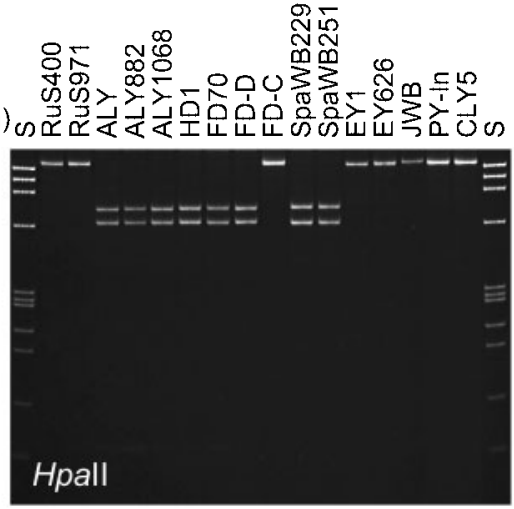

(d)

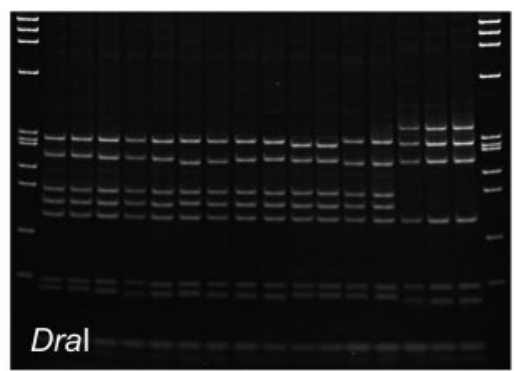

(g)

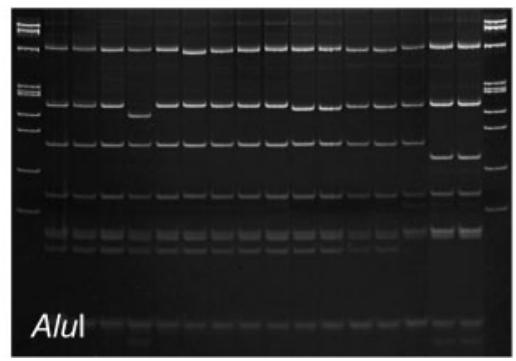

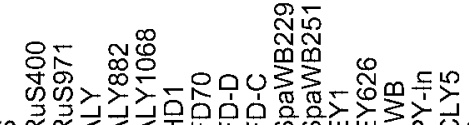

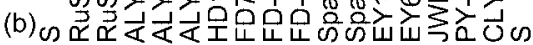

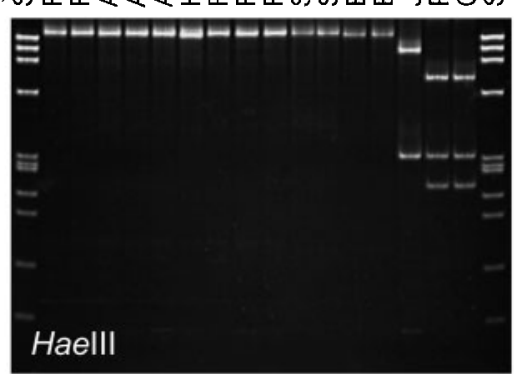

(e)

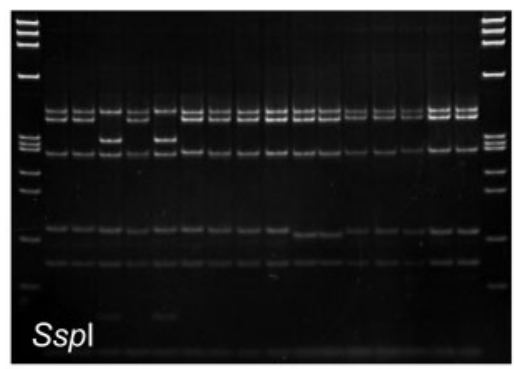

(h)

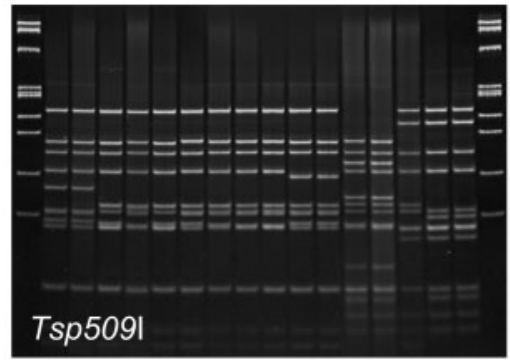

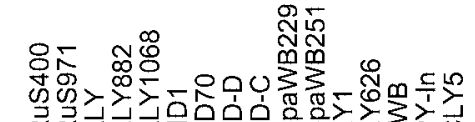

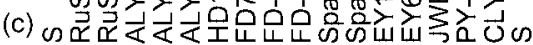

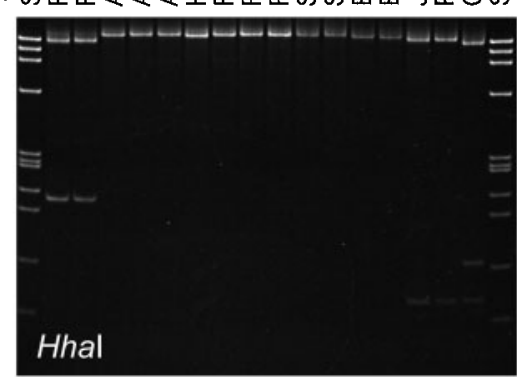

(f)

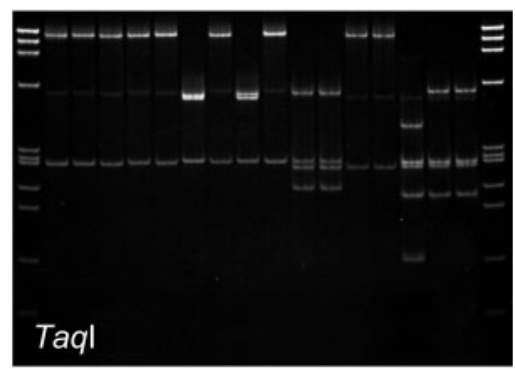

(i)

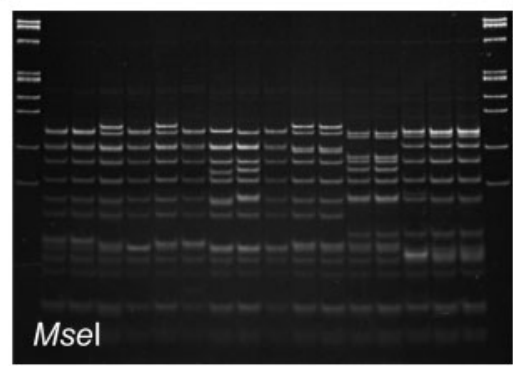

Fig. 2. RFLP profiles of ribosomal protein operon sequence $(1 \cdot 2 \mathrm{~kb}$, contains $r p / 22$ and $r p s 3$ genes), amplified by nested $\mathrm{PCR}$ with primer pair $r p(\mathrm{~V}) \mathrm{F} 1 / \mathrm{rpR} 1$ followed by primer pair $r p(\mathrm{~V}) \mathrm{F} 1 \mathrm{~A} / \mathrm{rp}(\mathrm{V}) \mathrm{R} 1 \mathrm{~A}$ from representative phytoplasma strains in the EY phytoplasma group (16SrV). (a)-(f) PCR products were digested with Hpall (a), Haell (b), Hhal (c), Dral (d), Sspl (e) or Taql (f) and separated by electrophoresis through $5 \%$ polyacrylamide gels. Lanes S, $\phi$ X174 replicating form I DNA Haell digest (fragment sizes given in legend to Fig. 1). (g)-(i) PCR products digested with Alul (g), Tsp509l (h) or Msel (i) were separated through $12 \%$ polyacrylamide gels. Lanes S, $\phi$ X174 replicating form I DNA Haell digest (1353 bp fragment not shown). Other abbreviations are defined in Table 1. 
Fig. B). Subgroup $16 \mathrm{SrV}$-A strains were classified into two secYV subgroups, secYV-A $\left(E Y 1^{\mathrm{T}}\right)$ and secYV-M (EY626). The Italian strain EY626 contains additional MseI and Tsp509I sites that distinguish it from strain $E Y 1^{\mathrm{T}}$ from the USA. This finding confirms previous results (based on RFLP analysis of the FD9f/r PCR fragment) reported by Daire et al. (1997) and Angelini et al. (2001).

\section{Genetic variation assessed by comparative sequence analyses of three different conserved genes}

Genetic variation was determined on the basis of three conserved genes, 16S rRNA, ribosomal protein and $\sec Y$. Members of the EY phytoplasma group exhibited different degrees of genetic variability in these three genes. On the basis of the $16 \mathrm{~S}$ rRNA gene, the mean sequence similarity ranged from 98.6 to $99.0 \%$ among members of the EY phytoplasma group. However, more heterogeneity was evident when ribosomal protein and $\sec Y$ genes were analysed. The four EY phytoplasma strains $\left(\mathrm{EY} 1^{\mathrm{T}}\right.$, EY125, EY626 and EY627) in subgroup $16 \mathrm{SrV}-\mathrm{A}$, which are associated with EY-infected elms in North America and Europe, shared $99.9 \%$ sequence similarity in the $16 \mathrm{~S}$ rRNA gene, $99.7 \%$ in the ribosomal protein genes and $99.5 \%$ (based on two strains) in secY. The three strains (CLY5, PY-In and JWB) in subgroup $16 \mathrm{SrV}-\mathrm{B}$, which are associated with cherry, peach and jujube in Asia, shared 99.9\% sequence similarity in the $16 \mathrm{~S}$ rRNA gene, $99 \cdot 1-99 \cdot 7 \%$ in the ribosomal protein genes and $98 \cdot 5-99 \cdot 6 \%$ in $\sec Y$. In contrast, the seven representative strains (ALY, ALY882, HD1, FD70, FD-C, FD-D and SpaWB251) in subgroup 16SrV-C shared $99 \cdot 7-99 \cdot 9 \%$ sequence similarity in the $16 \mathrm{~S}$ rRNA gene, $94 \cdot 3-99 \cdot 0 \%$ in the ribosomal protein genes and $91 \cdot 1-$ $97 \cdot 2 \%$ in $\sec Y$. More genetic variation was observed when two $16 \mathrm{SrV}$ subgroups were compared. Mean sequence similarity among representative $16 \mathrm{SrV}$ subgroups ranged from $94 \cdot 2$ to $97 \cdot 4 \%$ for ribosomal protein genes and from

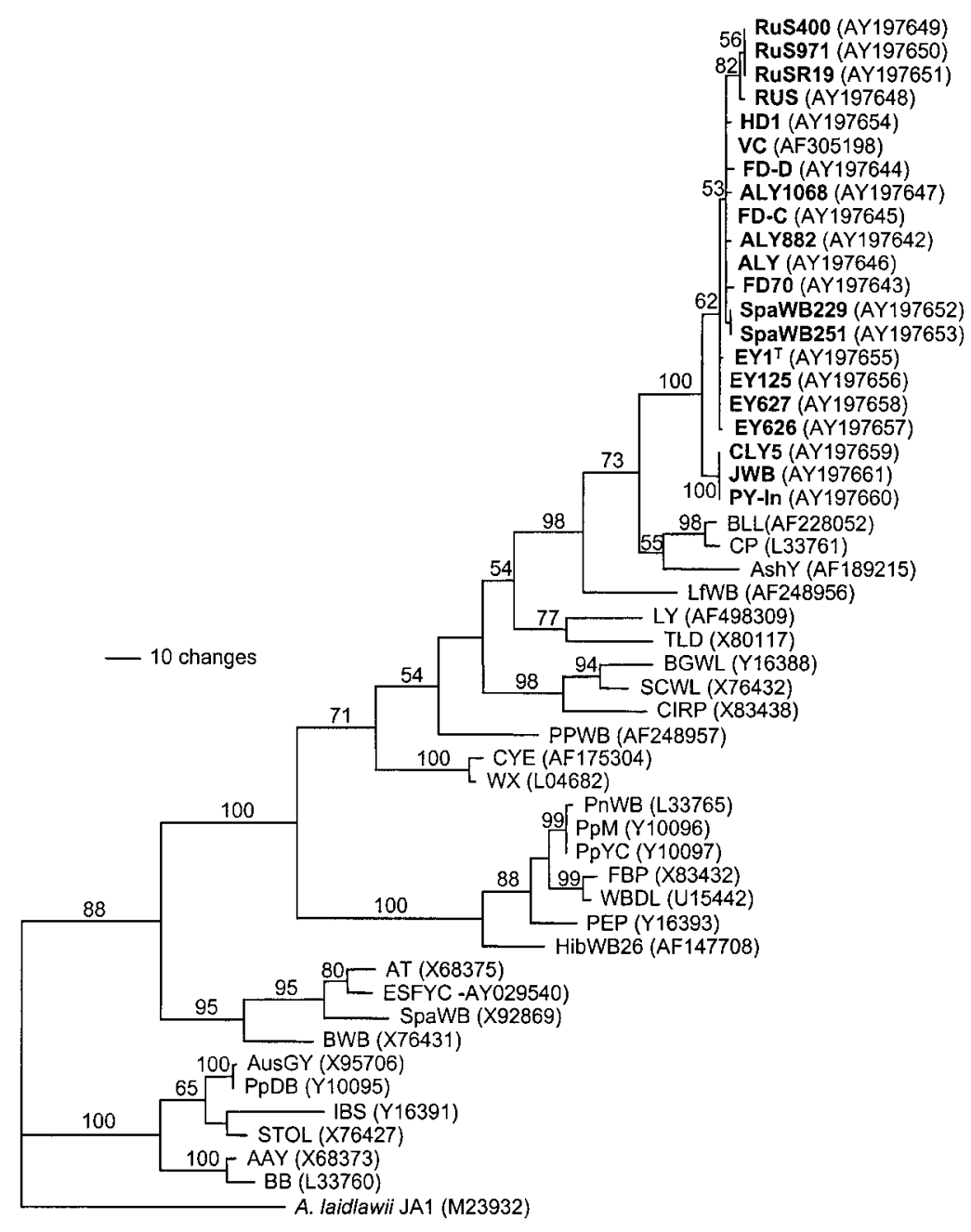

Fig. 3. Phylogenetic tree constructed by parsimony analysis of nearly full-length $16 \mathrm{~S}$ rDNA sequences from representative phytoplasma strains in the EY group (16SrV) and other $16 \mathrm{Sr}$ phytoplasma groups. Sequences were aligned with CLUSTAL V. A. laidlawii JA1 was used as the outgroup. Bar, 10 inferred character-state changes. Branch lengths are proportional to the number of inferred character-state transformations. Bootstrap values are shown on branches. Phytoplasmas or 'Candidatus Phytoplasma' species not included in Table 1 are: BLL, brinjal little leaf; $\mathrm{CP}$, clover proliferation; AshY, ash yellows ('Candidatus Phytoplasma fraxini'); LfWB, loofah witches'-broom; LY, palm lethal yellowing; TLD, Tanzanian lethal decline of coconut; BGWL, bermudagrass white leaf; SCWL, sugar-cane white leaf; CIRP, cirsium phyllody; PPWB, pigeon pea witches'-broom; CYE, clover yellow edge; WX, Western X; PnWB, peanut witches'broom; PpM, papaya mosaic; PpYC, papaya yellow crinkle ('Candidatus Phytoplasma australasia'); FBP, faba bean phyllody; WBDL, witches'-broom disease of lime ('Candidatus Phytoplasma aurantifolia'); PEP, Picris echioides phyllody; HibWB26, hibiscus witches'-broom ('Candidatus Phytoplasma brasiliense'); AT, apple proliferation; ESFYC, European stone fruit yellows; SpaWB, spartium witches'-broom; BWB, buckthorn witches'broom; AUGY, Australian grapevine yellows ('Candidatus Phytoplasma australiense'); PpDB, papaya dieback; IBS, Italian bindweed stolbur; STOL, stolbur of pepper; AAY, American aster yellows; BB, tomato big bud/Arkansas. GenBank accession numbers are indicated. 
83.2 to $91 \cdot 2 \%$ for $\sec Y$. For example, the mean sequence similarity between subgroup $16 \mathrm{SrV}$-A strains and strains in other subgroups was $99 \cdot 46 \%$ for $16 \mathrm{~S}$ rRNA gene, $96.66 \%$ for ribosomal protein genes and $86 \cdot 48 \%$ for $\sec Y$. The mean sequence similarity between subgroup $16 \mathrm{SrV}$-A strains and subgroup $16 \mathrm{SrV}-\mathrm{B}$ strains was $99 \cdot 3 \%$ for $16 \mathrm{~S}$ rRNA gene, $95 \cdot 8 \%$ for ribosomal protein genes and $80.46 \%$ for $\sec Y$. The EY group phytoplasmas exhibited slightly more variation in amino acid sequences deduced from the ribosomal protein and $\sec Y$ genes.

\section{Phylogenetic relationships}

Phylogenetic analysis using nearly full-length $16 \mathrm{~S}$ rDNA sequences of $20 \mathrm{EY}$ group phytoplasmas, 26 representative phytoplasmas of distinct phytoplasma groups or subgroups and Acholeplasma laidlawii (as an outgroup) resulted in 20 equally parsimonious trees. One of the most parsimonious trees is presented in Fig. 3. The EY group phytoplasmas represented a distinct strain cluster (or subclade) in the phytoplasma clade. The following are close relatives of the EY group: clover proliferation phytoplasma (reference strain for the 16SrVI group), brinjal little leaf phytoplasma and ash yellows phytoplasma, 'Candidatus Phytoplasma fraxini' (reference strain for the 16SrVII group). Within the EY phytoplasma subclade, strain FD-D (subgroup 16SrV-D) and members of subgroup $16 \mathrm{SrV}-\mathrm{C}$ clustered together. Flanked with this cluster were members of subgroup 16SrV-E, RuS phytoplasmas, and subgroup 16SrV-A EY phytoplasmas. Members of 16SrV-B (strains CLY5, JWB and PY-In) formed a distinct lineage distantly related to all other members of the EY group. However, because of the high degree of similarity shared by members of the EY phytoplasma group, not all of the 16Sr subgroups identified by RFLP analysis were resolved into distinct phylogenetic lineages based on 16S rRNA gene sequence. Phylogeny based on ribosomal protein genes revealed more phylogenetic divergence in the EY phytoplasma group. One of the seven most parsimonious trees is presented in Fig. 4(a). Twelve distinct phylogenetic lineages were resolved; these were clustered into three major phylogenetic groups, as indicated by high bootstrap values ( $>96 \%$ ): (i) a group including all representative phytoplasma strains in subgroups $16 \mathrm{SrV}-\mathrm{C}, 16 \mathrm{SrV}-\mathrm{D}$ and $16 \mathrm{SrV}-\mathrm{E}$; (ii) a group including four EY strains in subgroup $16 \mathrm{SrV}$-A; and (iii) a group including strains CLY5, PY-In and JWB in subgroup $16 \mathrm{SrV}-\mathrm{B}$. The 12 lineages were consistent with designated ribosomal protein subgroups based on RFLP analysis (Table 1). However, the phylogenetic relationships among strains FD, ALY, RuS and SpaWB were not well resolved, as indicated by the low bootstrap value $(<50 \%)$. Phylogeny based on the $\sec Y$ gene delineated 12 distinct lineages similar to those based on ribosomal protein genes, but the branching patterns of strains FD, ALY, RuS and SpaWB differed (Fig. 4b). The divergence of the 12 lineages became more apparent on the basis of secY. Phylogenetic analysis based on combined 16S rRNA and ribosomal protein gene sequences, or based on combined 16S rRNA, ribosomal protein and $\sec Y$ gene sequences, resulted in a tree congruent with that inferred by analysis of the ribosomal protein or $\sec Y$ gene (data not shown). As indicated by nucleotide sequence analyses, phylogenetic analysis using amino acid sequences deduced from ribosomal protein and $\sec Y$ genes showed that strains CLY5, JWB and PY-In formed a distinct cluster highly divergent from all the other strains in the EY phytoplasma group (data not shown).

\section{Conclusions}

Sequence analysis of the 16S rRNA gene is probably the most widely used method for the determination of phylogenetic relationships and for molecular classification of micro-organisms (Fox et al., 1992; Stackebrandt \& Goebel, 1994; Weisburg et al., 1989; Woese, 1987). This approach has been very useful for the classification of microorganisms at the genus level or for higher taxonomic ranks. Because of its highly conserved nature, however, the $16 \mathrm{~S}$ rRNA gene sequence is not very useful for differentiation at the species level (Fox et al., 1992; Stackebrandt \& Goebel, 1994). Often, additional molecular, biochemical or biological criteria are needed for accurate speciation. We have (a)

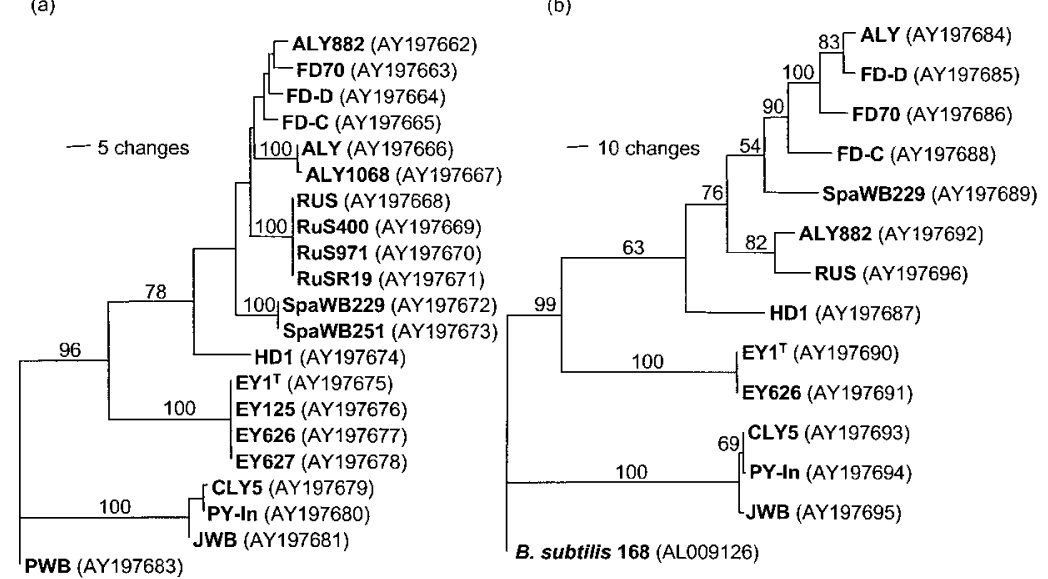

Fig. 4. Phylogenetic trees constructed by parsimony analyses of partial ribosomal protein operon (covering rp/22 and rps3 genes) (a) and secY gene (b) sequences from representative phytoplasma strains in the $E Y$ group (16SrV). Sequences were aligned with CLUSTAL V. Outgroup sequences are detailed in Methods. Bar length represents inferred character-state changes. Branch lengths are proportional to the number of inferred character-state transformations. Bootstrap values are shown on branches. Strain abbreviations are defined in Table 1. GenBank accession numbers are indicated. 
encountered a similar situation with respect to phytoplasmal classification. In the past decade, phytoplasmas have been classified primarily on the basis of the $16 \mathrm{~S}$ rRNA gene sequence (Lee et al., 1998a; Seemüller et al., 1998). More than 20 major phytoplasma groups and more than 40 subgroups have been identified. The difference in $16 \mathrm{~S}$ rDNA sequence between two groups is $2 \cdot 3 \%$ or more. There is a consensus that each group should represent at least one separate species (Gundersen et al., 1994; Jung et al., 2002; Lee et al., 1998a; Seemüller et al., 1998). So far, of the nine 'Candidatus Phytoplasma' species proposed (Davis et al., 1997; Griffiths et al., 1999b; Jung et al., 2002, 2003; Montano et al., 2001; Sawayanagi et al., 1999; Verdin et al., 2003; White et al., 1998; Zreik et al., 1995), two ('Candidatus Phytoplasma aurantifolia' and 'Candidatus Phytoplasma australasia') belong to subgroups in the peanut witches'broom group (= group 16SrII) according the classification scheme proposed by Lee et al. (1998a). The other six are 'Candidatus Phytoplasma fraxini' (16SrVII-A), 'Candidatus Phytoplasma australiense' (16SrXII-B), 'Candidatus Phytoplasma japonicum' (a strain closely related to members of 16SrXII), 'Candidatus Phytoplasma brasiliense' (16SrXV-A), 'Candidatus Phytoplasma castaneae' (most closely related to palm lethal yellows group 16SrIV), 'Candidatus Phytoplasma phoenicium' (16SrIV-B) and 'Candidatus Phytoplasma ziziphi' (16SrV-B). According to the recently revised scheme, the EY phytoplasma group ( $=16 \mathrm{SrV}$ group) was subdivided into five subgroups on the basis of RFLP analyses of 16S rDNA sequences (Lee et al., 1998a; Davis \& Dally, 2001; Martini et al., 1999). The variation in 16S rDNA sequence between two subgroups ranged from $0 \cdot 2$ to $1 \cdot 4 \%$. The relatively small variation makes it unclear whether the EY phytoplasma group should represent more than one species. However, biological and ecological differences among these five subgroups strongly suggest that the EY group consists of highly heterogeneous phytoplasma strains.

In the present study, we performed comparative analyses using the 16S rRNA gene and two more variable genes, the ribosomal protein gene operon and the $\sec Y$ gene, encoding a translocase protein, for strain differentiation in the EY phytoplasma group. Phylogenetic analysis based on the ribosomal protein genes or $\sec Y$ indicated several distinct lineages in the EY phytoplasma group. This result has underscored the need to employ phylogenetic molecular parameters that are genetically more variable for finer strain differentiation within a given phytoplasma group that was defined on the basis of the highly conserved 16S rRNA gene. By including ribosomal protein and $\sec Y$ genes for analyses, we have gained some insights into the diversity of the EY group phytoplasmas.

In contrast to subgroups defined by $16 \mathrm{~S}$ rDNA sequences, the majority of the subgroups differentiated on the basis of ribosomal protein or $\sec Y$ gene sequences appeared to be consistent with their specific ecological niches (specific host plants, vectors or geographical regions). For example, subgroup $16 \mathrm{SrV}-\mathrm{C}$ consists of a rather heterogeneous phytoplasma strain cluster that is associated with diverse plant and insect hosts. The constituent members in subgroup $16 \mathrm{SrV}-\mathrm{C}$ were subdivided into seven ribosomal protein subgroups, or seven secY subgroups, each of which is associated with a single, closely related plant host. Crossinfection of two or more plant species by members of a given ribosomal protein subgroup or secY subgroup seems to be rare, but a given disease (e.g. FD or ALY) could be attributed to more than one type of phytoplasma. For instance, Italian (strains ALY, ALY1068) and German (strain ALY882) ALY phytoplasma strains represented two distinct lineages on the basis of ribosomal protein or $\sec Y$ gene sequences. The phytoplasma strain cluster associated with FD in the grapevine was subdivided into four ribosomal protein subgroups (three identified in this work) (see Table 1): three subgroups occurred in Italy and two in France (Martini et al., 2002). On the basis of an analysis of the FD9 DNA sequence, the German ALY strain 882 (subgroup rp-K) was very similar to grapevine yellows phytoplasma (Palatinate grapevine yellows) strains that were reported to cross-infect black alder and grapevine in Germany (Angelini et al., 2001). Phytoplasma strains that are associated with grapevine yellows disease in grapevine in Germany are transmitted by the alder-feeding Oncopsis alni and cannot be transmitted by Scaphoideus titanus, the vector of FD phytoplasma strains associated with FD in France and Italy (Maixner et al., 1995). Members of subgroup $16 \mathrm{SrV}-\mathrm{A}$, which are associated with Ulmus spp., and subgroup $16 \mathrm{SrV}-\mathrm{E}$, which are associated with Rubus spp., represented two rather homogeneous strain clusters, based on phylogenetic analyses of both $16 \mathrm{~S}$ rRNA and ribosomal protein genes. Members of subgroup $16 \mathrm{SrV}-\mathrm{B}$ (consisting of CLY5, PY-In and JWB) were subdivided into three ribosomal protein subgroups or three secY subgroups. The three strains are associated with different plant hosts, and strain JWB is known to be transmitted by Hishimonoides chinensis (Tian et al., 2000; Zhu et al., 1997).

Phylogenies based on the ribosomal protein and $\sec Y$ genes revealed that phytoplasma strains that constitute the EY group are more heterogeneous than was indicated by analysis based on the 16S rRNA gene. On the basis of combined analyses of $16 \mathrm{~S}$ rRNA, ribosomal protein and $\sec Y$ gene sequences, the EY phytoplasma group clearly consists of at least three genetically distinct strain clusters represented by subgroups $16 \mathrm{SrV}-\mathrm{A}, 16 \mathrm{SrV}-\mathrm{B}$ and $16 \mathrm{SrV}-\mathrm{C}$. The degree of genetic variability among strain clusters increased when analysed using ribosomal protein or $\sec Y$ gene sequences. The phylogenetic divergence and ecological constraints specific for each strain cluster in the EY phytoplasma group suggest that each strain cluster should represent one species.

According to the recommendation of the International Committee of Systematics of Prokaryotes Subcommittee on the taxonomy of Mollicutes, two phytoplasmas that share more than $97 \cdot 5 \% 16 \mathrm{~S}$ rRNA gene sequence similarity but 
clearly represent ecologically separated populations can be designated as separate 'Candidatus Phytoplasma' species if they meet the following three criteria: (i) they are transmitted by different vectors; (ii) the two phytoplasmas have a different natural plant host(s); and (iii) there is evidence of molecular diversity between the two phytoplasmas (Anonymous, 2000). All three distinct phylogenetic strain clusters resolved by analysis of the ribosomal protein gene operon or the $\sec Y$ gene appear to fulfil the first two criteria and some of the third criterion as well. We propose that each of the three strain clusters should be a potential candidate for a separate 'Candidatus' species when the third criterion is fulfilled.

A novel 'Candidatus' species has been proposed for strain JWB, a member of the $16 \mathrm{SrV}$-B subgroup (Jung et al., 2003). In this work, we propose that EY phytoplasma strain $\mathrm{EY} 1^{\mathrm{T}}$ (a member of the $16 \mathrm{SrV}$-A subgroup) be assigned to a novel 'Candidatus' species on the basis of three criteria. (i) The $16 \mathrm{SrV}$-A phytoplasmas shared $<97.5 \%$ sequence similarity with all known phytoplasmas belonging to other phytoplasma groups and showed 98.2\% 16S rRNA gene sequence similarity, $93 \%$ similarity in the ribosomal protein genes and $81.0 \%$ similarity in the $\sec Y$ gene with respect to strain JWB phytoplasma. (ii) Phylogenetic analyses based on the three genes clearly indicated that the 16SrV-A strain cluster (consisting of strains EY1 ${ }^{\mathrm{T}}, \mathrm{EY} 125, \mathrm{EY} 626$ and EY627) represents a distinct lineage divergent from the 16SrV-B strain cluster (consisting of CLY5, PY-In and JWB) in the EY group. Subgroups 16SrV-A and 16SrV-B can be differentiated by PCR using a primer pair specific to subgroup $16 \mathrm{SrV}-\mathrm{B}$ (designed previously; Zhu et al., 1997). (iii) There are no plant hosts or vectors common to $16 \mathrm{SrV}-\mathrm{A}$ and $16 \mathrm{SrV}-\mathrm{B}$ phytoplasmas; strain $\mathrm{EY} 1^{\mathrm{T}}$ was transmitted by Scaphoideus luteolus (Sinclair et al., 1976). On the basis of the guidelines proposed by Murray \& Schleifer (1994), the $16 \mathrm{SrV}-\mathrm{A}$ phytoplasma $\mathrm{EY} 1^{\mathrm{T}}$ is designated as a novel species with the following description. 'Candidatus Phytoplasma ulmi': [(Mollicutes) NC; NA; O, wall-less; NAS (GenBank accession nos AY197655, AY197675, AY197690); oligonucleotide sequences of unique regions of $16 \mathrm{~S}$ rRNA, rpl22-rps3 and secY genes, as shown in Table 2. P (Ulmus

Table 2. Sequences unique to 'Candidatus Phytoplasma ulmi' in 16S rRNA, rp/22-rps3 and secY genes

\begin{tabular}{|llc|}
\hline Gene & Signature sequence $\left(\mathbf{5}^{\prime} \mathbf{-} \mathbf{3}^{\prime}\right)$ & Position \\
\hline \multirow{2}{*}{ 16S rRNA } & GGAAA & $827-835$ \\
& CGTTAGTTGCC & $1098-1108$ \\
& TTACGCTTGCC 3 & $284-294$ \\
& CATTTAATAAAATTGCTATT & $739-758$ \\
\multirow{3}{*}{ sec $Y$} & AAATTCTATTTCTATGGGAAT & $910-932$ \\
& TTTGATCCAATGTTAA & $350-365$ \\
& GTCTTTCGGTCATGGATTGA & $595-614$ \\
& ATTTAGTCTAAT & $616-627$ \\
& CAAATAGAACAA & $1053-1064$ \\
\hline
\end{tabular}

americana, phloem); $\mathrm{M}] . \mathrm{EY}^{\mathrm{T}}$ is the reference strain. Related phytoplasmas include strains EY125, EY626 and EY627, associated with Ulmus minor. 16SrV-A phytoplasma strains cause diseases in Ulmus spp. and induce symptoms including epinasty, yellowing, dwarfing and premature casting of leaves, witches'-brooms at the tips of twigs and branches and precocious opening of vegetative buds.

\section{ACKNOWLEDGEMENTS}

Some of this work was presented as part of the doctoral thesis of M.M. M.M. was a visiting scientist in the Molecular Plant Pathology Laboratory, USDA-ARS, Beltsville, MD, USA. We gratefully acknowledge Kristi Bottner for technical assistance with manuscript preparation and Yung-Chia Chen for technical assistance.

\section{REFERENCES}

Ahrens, U. \& Seemüller, E. (1992). Detection of DNA of plant pathogenic mycoplasmalike organisms by a polymerase chain reaction that amplifies a sequence of the 16S rRNA gene. Phytopathology 82, 828-832.

Angelini, E., Clair, D., Borgo, M., Bertaccini, A. \& Boudon-Padieu, E. (2001). Flavescence dorée in France and Italy - occurrence of closely related phytoplasma isolates and their near relationships to Palatinate grapevine yellows and an alder yellows phytoplasma. Vitis 40, 79-86.

Anonymous (2000). Phytoplasmas, spiroplasmas, mesoplasmas and entomoplasmas working team. In International Research Program on Comparative Mycoplasmology (IRPCM) of the International Organization for Mycoplasmology (IOM) Report of Consultations, July 2000. Fukuoka, Japan.

Bertaccini, A., Vibio, M., Schaff, D. A., Murari, E., Martini, M. \& Danielli, A. (1997). Geographical distribution of elm yellows-related phytoplasmas in grapevine Flavescence dorée outbreaks in Veneto (Italy). In Extended Abstracts of the 12th Meeting of the International Council for the Study of Virus and Virus-like Diseases of the Grapevine, pp. 57-58. Lisbon, 28 September-2 October 1997. Oeiras: Departamento de Fitopatologia-Estação Agronómica Nacional.

Daire, X., Clair, D., Reinert, W. \& Boudon-Padieu, E. (1997). Detection and differentiation of grapevine yellows phytoplasmas belonging to elm yellows group and to the stolbur subgroup by PCR amplification of non-ribosomal DNA. Eur J Plant Pathol 103, 507-514.

Davis, R. E. \& Dally, E. L. (2001). Revised subgroup classification of group $16 \mathrm{SrV}$ phytoplasmas and placement of Flavescence doréeassociated phytoplasmas in two distinct subgroups. Plant Dis 85, 790-797.

Davis, R. E., Dally, E. L., Gundersen, D. E., Lee, I.-M. \& Habili, N. (1997). "Candidatus Phytoplasma australiense," a new phytoplasma taxon associated with Australian grapevine yellows. Int $J$ Syst Bacteriol 47, 262-269.

Del Serrone, P., Marzachì, C., Bragaloni, M. \& Galeffi, P. (2001). Phytoplasma infection of tomato in central Italy. Phytopathol Mediterr 40, 137-142.

Fox, G. E., Wisotzkey, J. D. \& Jurtshuk, P., Jr (1992). How close is close: $16 \mathrm{~S}$ rRNA sequence identity may not be sufficient to guarantee species identity. Int J Syst Bacteriol 42, 166-170.

Griffiths, H. M., Sinclair, W. A., Boudon-Padieu, E., Daire, X., Lee, I.-M., Sfalanga, A. \& Bertaccini, A. (1999a). Phytoplasmas associated with elm yellows: molecular variability and differentiation from related organisms. Plant Dis 83, 1101-1104. 
Griffiths, H. M., Sinclair, W. A., Smart, C. D. \& Davis, R. E. (1999b). The phytoplasma associated with ash yellows and lilac witches'broom: 'Candidatus Phytoplasma fraxini'. Int J Syst Bacteriol 49, 1605-1614.

Gundersen, D. E. \& Lee, I.-M. (1996). Ultrasensitive detection of phytoplasmas by nested-PCR assays using two universal primer pairs. Phytopathol Mediterr 35, 144-151.

Gundersen, D. E., Lee, I.-M., Rehner, S. A., Davis, R. E. \& Kingsbury, D. T. (1994). Phylogeny of mycoplasmalike organisms (phytoplasmas): a basis for their classification. J Bacteriol 176, 5244-5254.

Gundersen, D. E., Lee, I.-M., Schaff, D. A., Harrison, N. A., Chang, C. J., Davis, R. E. \& Kingsbury, D. T. (1996). Genomic diversity and differentiation among phytoplasma strains in $16 \mathrm{~S}$ rRNA groups I (aster yellows and related phytoplasmas) and III (X-disease and related phytoplasmas). Int J Syst Bacteriol 46, 64-75.

Harrison, N. A., Griffiths, H. M., Carpio, M. L. \& Richardson, P. A. (2001). Detection and characterization of an elm yellows (16SrV) group phytoplasma infecting Virginia creeper plants in southern Florida. Plant Dis 85, 1055-1062.

Higgins, D. G. \& Sharp, P. M. (1989). Fast and sensitive multiple sequence alignments on a microcomputer. Comput Appl Biosci 5, 151-153.

Jung, H.-Y., Sawayanagi, T., Kakizawa, S. \& 7 other authors (2002). 'Candidatus Phytoplasma castaneae', a novel phytoplasma taxon associated with chestnut witches' broom disease. Int J Syst Evol Microbiol 52, 1543-1549.

Jung, H.-Y., Sawayanagi, T., Kakizawa, S. \& 7 other authors (2003). 'Candidatus Phytoplasma ziziphi', a novel phytoplasma taxon associated with jujube witches'-broom disease. Int J Syst Evol Microbiol 53, 1037-1041.

Lee, I.-M., Davis, R. E., Sinclair, W. A., DeWitt, N. D. \& Conti, M. (1993a). Genetic relatedness of mycoplasmalike organisms detected in Ulmus spp. in the United States and Italy by means of DNA probes and polymerase chain reactions. Phytopathology 83, 829-833.

Lee, I.-M., Hammond, R. W., Davis, R. E. \& Gundersen, D. E. (1993b). Universal amplification and analysis of pathogen $16 \mathrm{~S}$ rDNA for classification and identification of mycoplasmalike organisms. Phytopathology 83, 834-842.

Lee, I.-M., Bertaccini, A., Vibio, M., Gundersen, D. E., Davis, R. E., Mittempergher, L., Conti, M. \& Gennari, F. (1995). Detection and characterization of phytoplasmas associated with disease in Ulmus and Rubus in northern and central Italy. Phytopathol Mediterr 34, 174-183.

Lee, I.-M., Gundersen-Rindal, D. E., Davis, R. E. \& Bartoszyk, I. M. (1998a). Revised classification scheme of phytoplasmas based on RFLP analyses of $16 \mathrm{~S}$ rRNA and ribosomal protein gene sequences. Int J Syst Bacteriol 48, 1153-1169.

Lee, I.-M., Gundersen-Rindal, D. E. \& Bertaccini, A. (1998b). Phytoplasma: ecology and genomic diversity. Phytopathology 88, 1359-1366.

Lee, I.-M., Davis, R. E. \& Gundersen-Rindal, D. E. (2000). Phytoplasma: phytopathogenic mollicutes. Annu Rev Microbiol 54, 221-255.

Lim, P.-O. \& Sears, B. B. (1992). Evolutionary relationships of a plant-pathogenic mycoplasmalike organism and Acholeplasma laidlawii deduced from two ribosomal protein gene sequences. J Bacteriol 174, 2606-2611.

Maixner, M., Ahrens, U. \& Seemüller, E. (1995). Detection of the German grapevine yellows (Vergilbungskrankheit) MLO in grapevine, alternative hosts and a vector by a specific PCR procedure. Eur J Plant Pathol 101, 241-250.

Marcone, C., Ragozzino, A., Schneider, B., Lauer, U., Smart, C. D. \& Seemüller, E. (1996a). Genetic characterization and classification of two phytoplasmas associated with spartium witches'-broom disease. Plant Dis 80, 365-371.

Marcone, C., Ragozzino, A. \& Seemüller, E. (1996b). Detection of an elm yellows-related phytoplasma in eucalyptus trees affected by little-leaf disease in Italy. Plant Dis 80, 669-673.

Marcone, C., Ragozzino, A. \& Seemüller, E. (1997). Identification and characterization of the phytoplasma associated with elm yellows in southern Italy and its relatedness to other phytoplasmas of the elm yellows group. Eur J Forest Pathol 27, 45-54.

Martini, M., Murari, E., Mori, N. \& Bertaccini, A. (1999). Identification and epidemic distribution of two Flavescence dorée-related phytoplasmas in Veneto (Italy). Plant Dis 83, 925-930.

Martini, M., Botti, S., Marcone, C., Marzachì, C., Casati, P., Bianco, P. A., Benedetti, R. \& Bertaccini, A. (2002). Genetic variability among Flavescence dorée phytoplasmas from different origins in Italy and France. Mol Cell Probes 16, 197-208.

Mäurer, R. \& Seemüller, E. (1994). Nature and genetic relatedness of the mycoplasma-like organism causing rubus stunt in Europe. Plant Pathol 44, 244-249.

Mäurer, R., Seemüller, E. \& Sinclair, W. A. (1993). Genetic relatedness of mycoplasmalike organisms affecting elm, alder, and ash in Europe and North America. Phytopathology 83, 971-976.

Montano, H. G., Davis, R. E., Dally, E. L., Hogenhout, S., Pimentel, J. P. \& Brioso, P. S. T. (2001). 'Candidatus Phytoplasma brasiliense', a new phytoplasma taxon associated with hibiscus witches' broom disease. Int J Syst Evol Microbiol 51, 1109-1118.

Murray, R. G. E. \& Schleifer, K. H. (1994). Taxonomic notes: a proposal for recording the properties of putative taxa of procaryotes. Int J Syst Bacteriol 44, 174-176.

Reinert, W. (1999). Detection and further differentiation of plant pathogenic phytoplasmas (Mollicutes, Eubacteria) in Germany regarding phytopathological aspects, p. 148 . PhD dissertation, Dem Fachbereich Biologie der Technischen Universität Darmstadt (in German).

Sawayanagi, T., Horikoshi, N., Kanehira, T., Shinohara, M., Bertaccini, A., Cousin, M.-T., Hiruki, C. \& Namba, S. (1999). 'Candidatus Phytoplasma japonicum', a new phytoplasma taxon associated with Japanese Hydrangea phyllody. Int J Syst Bacteriol 49, 1275-1285.

Schneider, B., Seemüller, E., Smart, C. D. \& Kirkpatrick, B. C. (1995). Phylogenetic classification of plant pathogenic mycoplasmalike organisms or phytoplasmas. In Molecular and Diagnostic Procedures in Mycoplasmology, vol. 2, pp. 369-380. Edited by S. Razin \& J. G. Tully. New York: Academic Press.

Seemüller, E., Schneider, B., Mäurer, R. \& 8 other authors (1994). Phylogenetic classification of phytopathogenic mollicutes by sequence analysis of $16 \mathrm{~S}$ ribosomal DNA. Int J Syst Bacteriol 44, 440-446.

Seemüller, E., Marcone, C., Lauer, U., Ragozzino, A. \& Göschl, M. (1998). Current status of molecular classification of the phytoplasmas. J Plant Pathol 80, 3-26.

Sinclair, W. A., Braun, E. J. \& Larsen, A. O. (1976). Update on phloem necrosis of elms. J Arboric 2, 106-113.

Stackebrandt, E. \& Goebel, B. M. (1994). Taxonomic note: a place for DNA-DNA reassociation and 16S rRNA sequence analysis in the present species definition in bacteriology. Int J Syst Bacteriol 44, 846-849.

Swofford, D. L. (1998). PAUP* ${ }^{*}$ Phylogenetic analysis using parsimony ( ${ }^{*}$ and other methods), version 4. Sunderland, MA: Sinauer.

Tian, J. B., Bertaccini, A., Martini, M., Paltrinieri, S., Guo, H. P. \& Pastore, M. (2000). Molecular detection of Jujube witches' broom 
phytoplasmas in micropropagated jujube shoots. HortScience 35, 1274-1275.

Verdin, E., Salar, P., Danet, J.-L., Choueiri, E., Jreijiri, F., El Zammar, S., Gélie, B., Bové, J. M. \& Garnier, M. (2003). 'Candidatus Phytoplasma phoenicium' sp. nov., a novel phytoplasma associated with an emerging lethal disease of almond trees in Lebanon and Iran. Int J Syst Evol Microbiol 53, 833-838.

Weisburg, W. G., Tully, J. G., Rose, D. L. \& 9 other authors (1989). A phylogenetic analysis of the mycoplasmas: basis for their classification. J Bacteriol 171, 6455-6467.

White, D. T., Blackall, L. L., Scott, P. T. \& Walsh, K. B. (1998).

Phylogenetic positions of phytoplasmas associated with dieback, yellow crinkle and mosaic diseases of papaya, and their proposed inclusion in 'Candidatus Phytoplasma australiense' and a new taxon, 'Candidatus Phytoplasma australasia'. Int J Syst Bacteriol 48, 941-951.

Woese, C. R. (1987). Bacterial evolution. Microbiol Rev 51, 221-271.

Zhu, S. F., Hadidi, A., Gundersen, D. E., Lee, I.-M. \& Zhang, C. L. (1997). Characterization of the phytoplasmas associated with cherry lethal yellows and jujube witches'-broom diseases in China. Acta Hortic 472, 701-714.

Zreik, L., Carle, P., Bové, J. M. \& Garnier, M. (1995). Characterization of the mycoplasmalike organism associated with witches'-broom disease of lime and proposition of a Candidatus taxon for the organism, "Candidatus Phytoplasma aurantifolia". Int J Syst Bacteriol 45, 449-453. 